
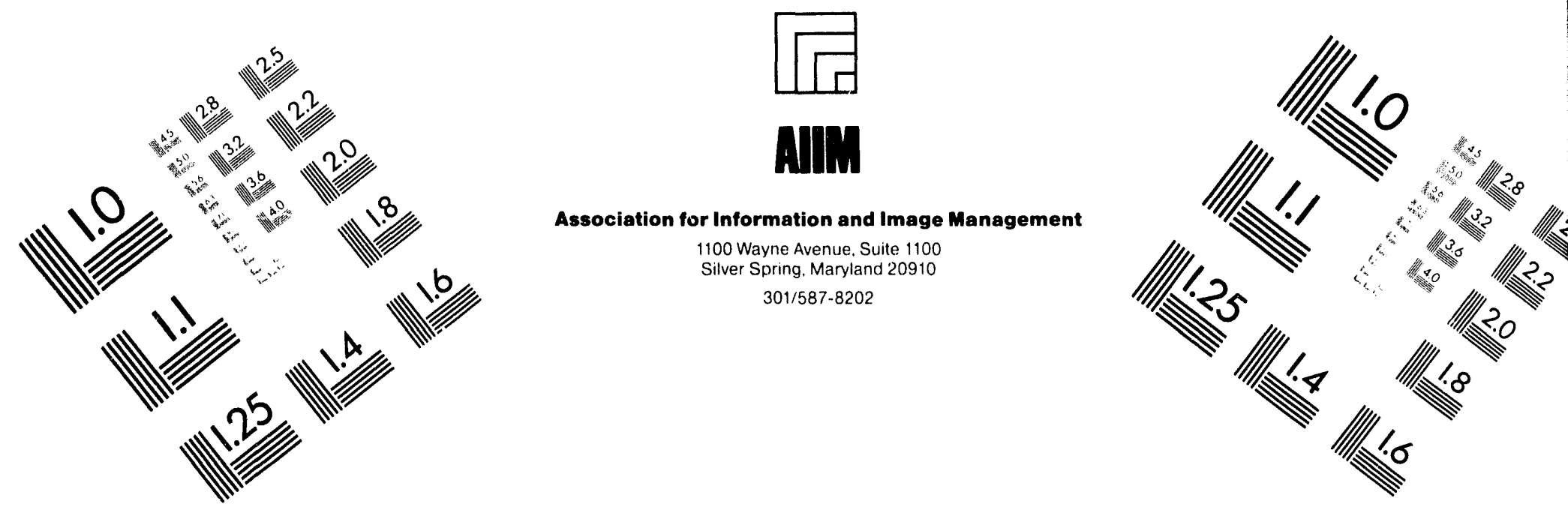

\title{
Centimeter
}

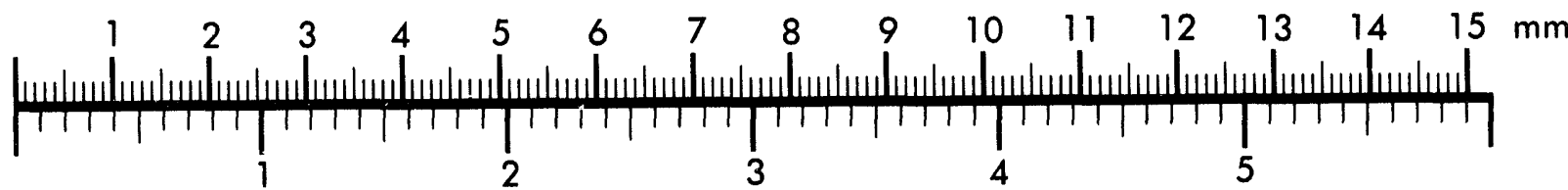

Inches
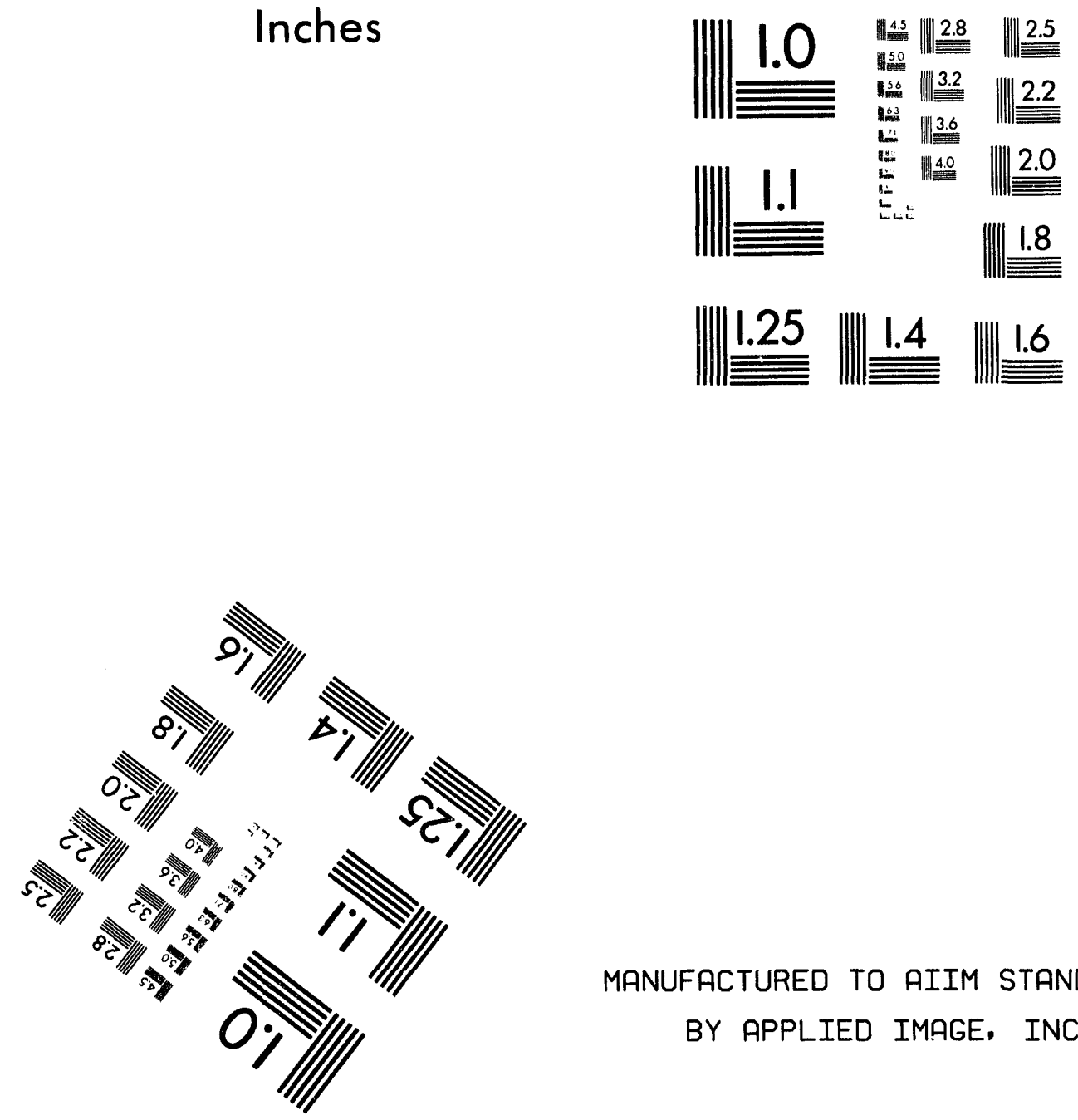

MANUFACTURED TO AIIM STANDARDS

BY APPLIED IMAGE, INC.

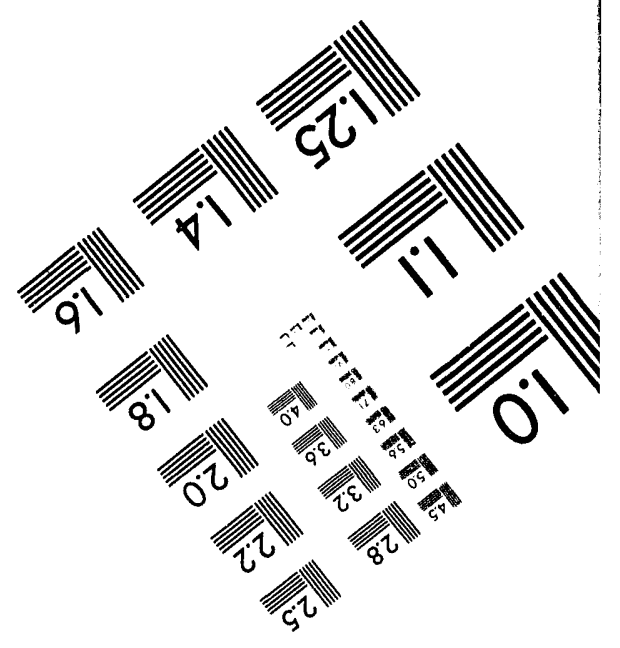



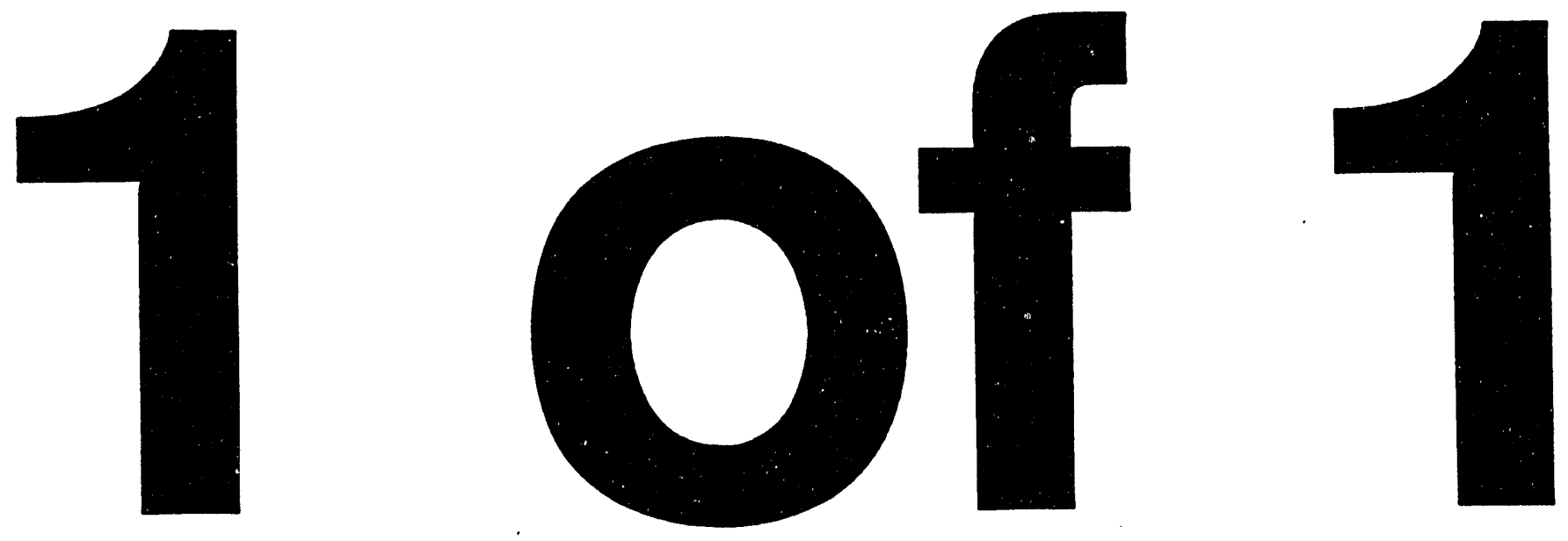


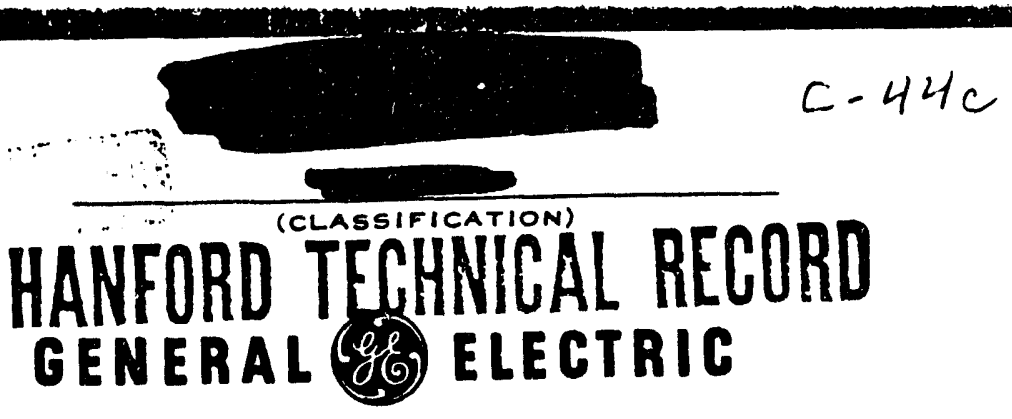

HANFORD ATOMIC PRODUCTS OPERATION - RICHLAND, WASHINGTON

DOCUMENT NO.

RI-REA-2160

SERIES AND CUPY NO.

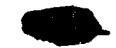

DATE

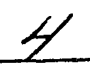

May 27,1965

\section{- $\sqrt{\mathrm{X}}$ RESTRICA D DATA \\ IS DOCUMENT CONTAINB ESTRICTED DATA AS D. WNED IN THE ATOMIC E MRGY ACT OF 1954. ITS TANSMITTAL OR THE DISO OSURE OF ITS CONTEN IN ANY MANNER TO AN D UUTHORIZED PERSON IST TRHIBITED. \\ OA ER OFFICIAL CLASSIFIED RORMATION THIS MD ERIAL CONTAINS INFORMAT N AFFECTING THE NATI LAL DEFENSE OF THE UI TED STATFS WITHIN THE MEANING OF THE ESPION EE LAWS. TITLE 10, U.S. SECS. 793 AND 794, Th TRANS- MISSION OR REVEL JON OF WHHICH IN ANY ANNER TO AN UNAUTHORIZED TRSON IS PROHIBITL EY LAW. \\ TITLE \\ REIEASE OF RADIOACTIVITY TO TETE COLIMBIA RIVER FROM IRRADIATED FUEL EIEMENT RUPTUTES \\ P. C. Jerman \\ W. N. KCop \\ F. E. Owen

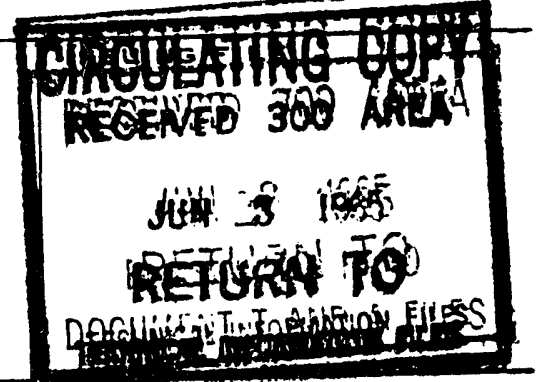
THIS DOCUMENT MUST NOT BE LEFT UNATTENDED OR WHERE AN UNAUTHORIZED PERSON MAY HAVE ACCESS TO IT. WHEN NOT IN ULETMUISTE STORED IN AN APPROVED LOCKED REPOSITORY WITHIN AN ARPROVED GUARDED AREA. WHILE IT IS YOUR POSOMAIONAND UNTIL YOU HAVE OBTAINED A SIGNED RECEIPT FROM CLASSIFIED FILES, IT IS YOUR RESPONSIBILITY TOM-T IT AND ITS CONTENTS WITHIN THE LIMITS OF THIS PROJECT AND FROM ANY UNAUTHORIZED PERSON. ITS TRMIMUTAAL TO, AND STORAGE AT YOUR PLACE OF RESIDENCE IS PROHIBITED. IT IS NOT TO BE DUPLICATED. IF MULULNAL COPIIS ARE REQUIRED, OBTAIN THEM FROM THE RELATED ISSUING FILE. ALL PERSONS READING THISLU TO SIGN IN THE SPACE PROVIDED BELOW.

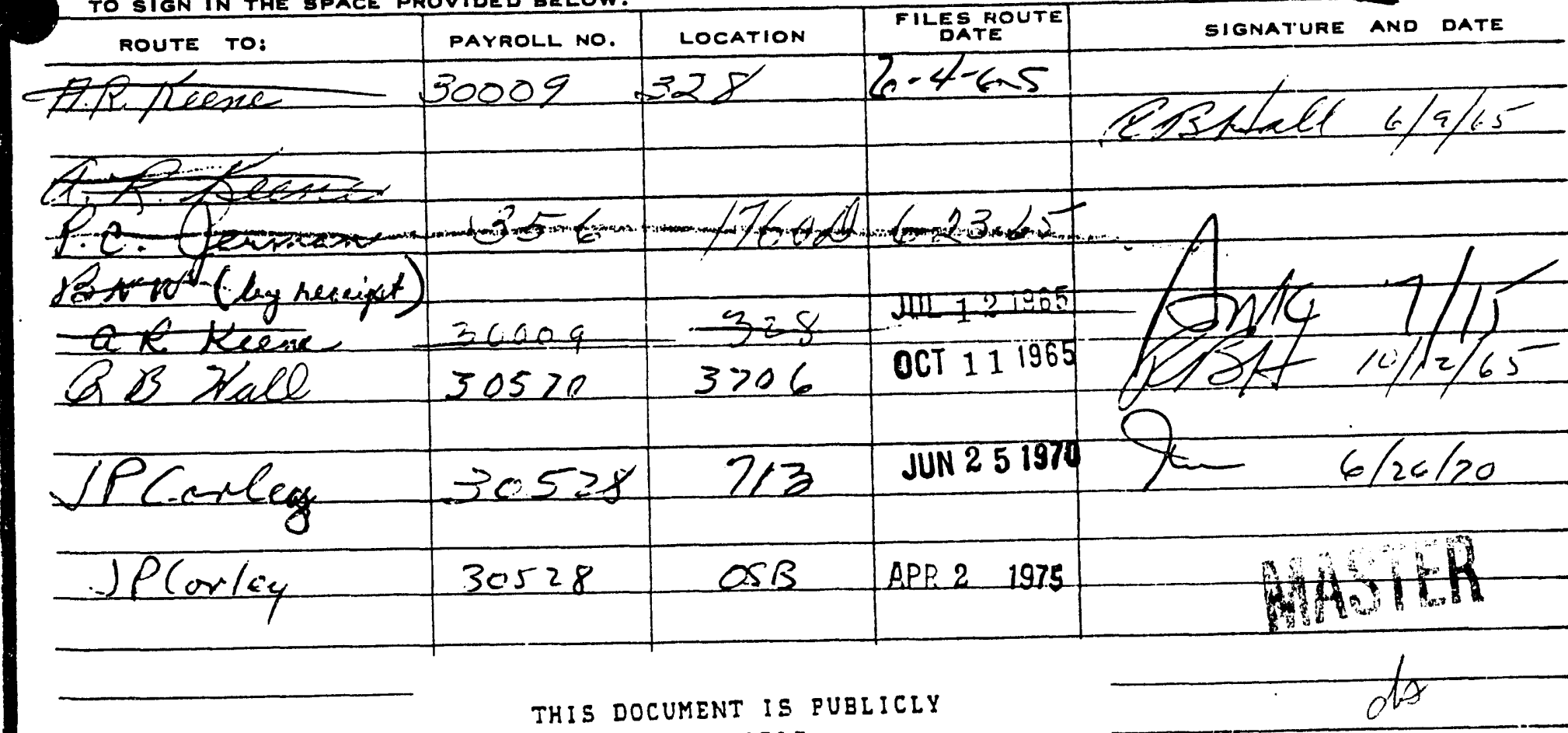




\section{RESTRICTED DATA}

Thindocument contains retricted data as defined in the Atomic Eners Act of 1954 . Its transuttal or the disclosuse of its contents in als manner to an unauhorized person is prohibithed.

\section{$-1-m-R I-R E A-2160$}

Tnis document consists of 9 pages, No. 4 of 15 copies. Series?

\section{REIEASE OF RADIOACTIVITY TO THE COLUMBIA RIVER} FROM IRRADIATED FUEL ELEMENT RUPTURES

Classkisctinn Cancelled Change to LSC'LSSIFIED

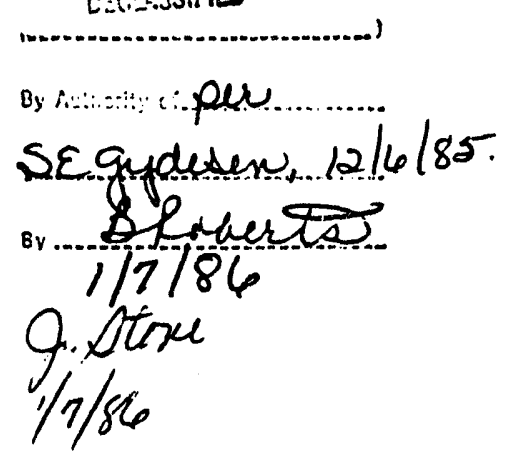

May 27, 1965

P. C. Jerman

W. N. Koop

F. E. Owen

\section{HANFORd ATOMIC PRODUCTS OpERATION RICHLAND. WASHINGTON}

\section{NOTICE}

This report was prepared for use within General Electric Company in the course of work under Atomic Energy Commission Contract AT(45-1) - 1350, and any views or opinions expressed in the report are those of the author only. This report is subject to revision upon collection of additional data.

\section{LEGAL NOTICE}

This report was prepared as an account of Government sponsored work. Neither the United States, nor the Commission, nor any person acting on behalf of the Commission:

A. Makes any warranty or representation, expressed or implied, with respect to the accuracy, completeness, or usefulness of the information contained in this report, or that the use of any information, opparatus, method, or process disclosed in this report may not infringe privately owned rights; or

B. Assumes ar $y$ liabilities with respect to the use of, or for damages resulting from the use of any information, appuratus, method, or process disclosed in this report.

As used in the above, "person acting on behalf of the Commission" includes any employee or contractor of the Commission, or employee of such confractor, to the extent that such employee or con. tractor of the Commission, or employee of such contractor prepares, disseminates, or provides access to, any information pursuant to his employment or contract with the Commission, or his employment with such contractor.
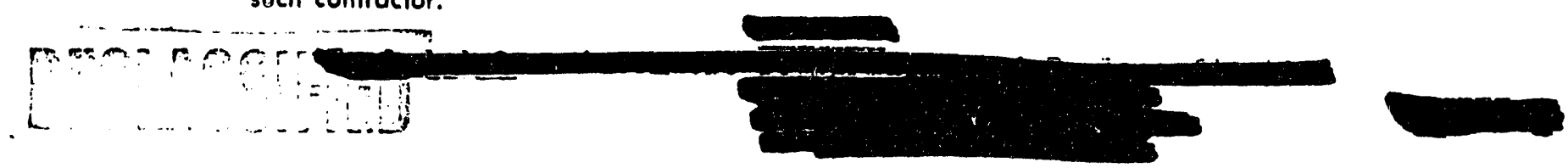


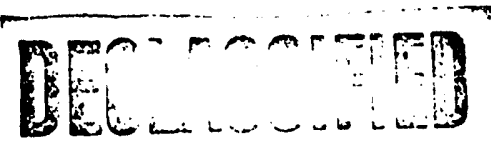

\section{DISTRIBUTION}

1-3. RLOO-AEC - Attn: AT Gifford

4. Battelle-Northwest - Attn: AR Keene

5. TW Ambrose

6. RG Geier

7. $A B$ Greninger

3. PC Jerman

9. RT Jessen

10. WE Johnson

11. $R$ Nilson

12. FE Owen

13. OC Schroeder

14. 700 Area File

15. Record File 

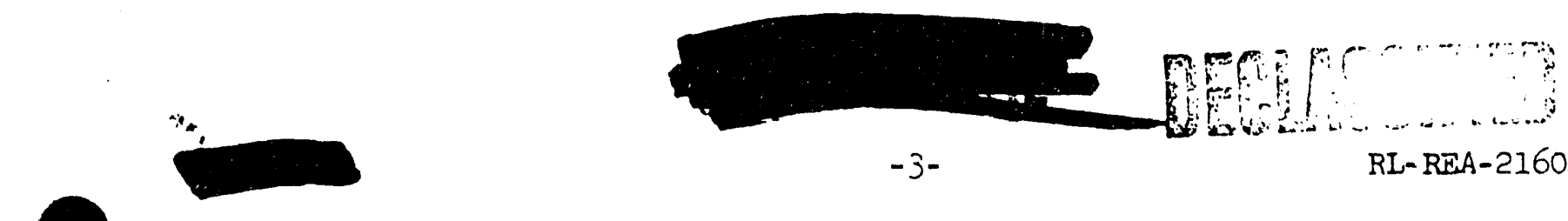

\section{REIEASE OF RLDIOACTIVITY TO THE COLUMEIA RIVER FROM IRRALIATED FUEI ELEMENT RUPTURES}

\section{INTRODUCTION}

McCormack and Schwendiman issued a report in $1959^{(1)}$ which estimated the amount of fission products from fuel element failures entering the Columbia River during the period 1952-1958 inclusive. Since that time there have been no attempts made to publish similar information for the subsequent years.

It is the purpose of this report to review the fuel element rupture experience of 1964 as somewhat typical of the last few years, and to estimate the amount of significant fission products which entered the Columbia River. The routine measurements of fission products both in the reactor effluent streams and in the Columbia River will be reviewed for comparison purposes.

\section{DISCUSSION}

\section{Ruptured Slug Experience}

There were 97 fuel element failures during calendar year 1964. Seventeen of these ruptured elements could not be fourd and identified in the routine search made after discharge. The gth 0 r 80 were examined, classified, photographed and/or sketches drawn (2). The "side hot spot" fallure classification was predominant, accounting for 64 of the 80 identified. Although none were weighed, an estimate of weight loss for each was made from the photographs, sketches and written descriptions made upor examination.

Table I lists the number of ruptured fuel elements experienced from 1955 through 1964.

\section{TABLE I}

\section{NUMBER OF RUPTURED FUEL ELEMENIS} 1955 through 1964

$\begin{array}{lr}1955 & 168 \\ 1956 & 167 \\ 1957 & 200 \\ 1958 & 173 \\ 1959 & 74 \\ 1960 & 138 \\ 1961 & 85 \\ 1962 & 93 \\ 1963 & 59 \\ 1964 & 97\end{array}$

The ruptured element frequency and weight losses sustained in 1964 were comfrarej to similaf gata from 1955 through 1958, the period stuaied by schweriinan ara McCormack ${ }^{2}$. There were airost twice as many fuel tement faildes during each 


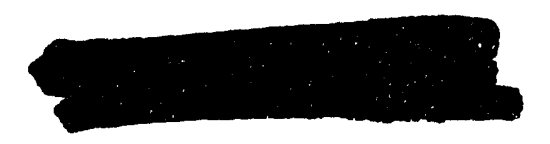

$-4-$

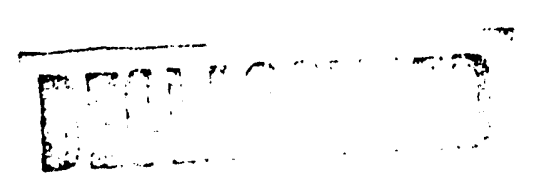

RL-REA-2160

of those earlier years as there were in 1964. About half of the ruptured elements of the earlier period were classified then as "severe" because of large penetrations of cladded sides and fragmenting of the metal. The estimated weight loss on that kind of fuel element fallure was 150 grams, while the others were estimated to have lost 9 grams each. The average weight loss during the se four years was about $12 \mathrm{~kg}$ or almost five times the total weight loss of $2.4 \mathrm{~kg}$ in 1964. The reduction in the number of ruptured elements per year and the loss of 1rradiated rupture debris per failure can be largely attributed to the improvements in design and fabrication of the fuel elements. As a result of three reactors being discontinued, the number of failures in the future can be expected to be further reduced.

\section{Significant Fission Product Discharge to the Columbia River}

There are two sources of fission products which contribute to the total fission product activity in the Columbia River. Uranium is naturally present in the river water used to cool the reactors. This uranium is subject to the reactor neutron flux and the U-235 fission while passing through. A small but significant portion, somewhat greater than $5 \%(3)(4)$, is absorbed on the aluminum surfaces for extended periods of time, developing a retention - release equilibrium with the cooling water. The other source of fission product is the irradiated uranium released from fuel elements when they rupture in the reactors.

Of the fission products which enter the river, lodine-131 is the most significant and is the only one which will be of concern in this report. It is the only one of all radionuclides. Which concentrates in the thyroid gland of humans, and its maximum permissible concentration in water is lower than for any of the other fission product radionuclides.

An estimated 2400 grams of irradiated uranium containing 920 curies of I- 131 were lost from fuel elements as a result of the 97 cladding failures during 1964. The uranium lost from any single fuel element ranged from a few grams to a maximum of about 100 grams with an average of 25 grams per failed element.

It is assumed that all of the I-13I contained in the uranium lost was delivered directly to the river. This will over-estimate the I-I3I release because a portion of it will remain occluded in the uranium to be leached at a later date after a significant reduction by radioactive decay. The distribution of the estimated 920 curies released over the year 1964 is shown in Figure 1.

During 1964 about $500 \mathrm{~kg}$ of natural uranium in the cooling water passed through the eight reactors creating about 800 curies of I-131. Most of the fissioning occurs while uranium is retained on the tube and fuel element surfaces, releasing the I-13I into the effluent water. The amount of I-I3I varies throughout the year, which can be seen in Figure 1 .
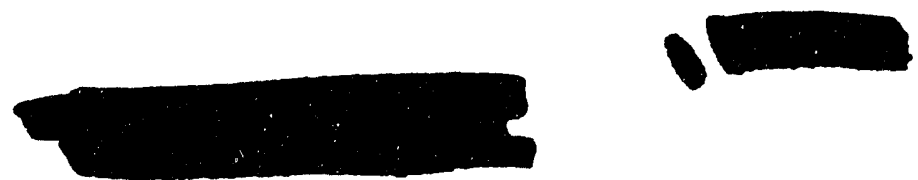



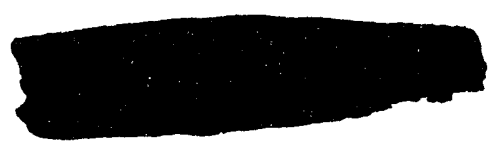

$-6-$

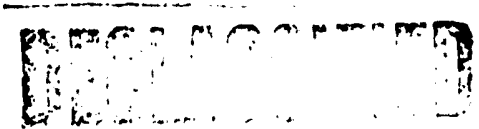

RI-REA-2.150

River sampling devices, installed and operated by Hanford Laboratories personnel, composited water samples during all of 1964. The se weekly. integrated samples were collected off-shore near the 300 Area from prior to the first of the year until mid-August. Starting in mid-June and continuing after the end of 1964, samples were also collected with a similar device at the Richland Water Plart intake. These samples were analyzed for I-I3I as well as several other radionuclides.

The amount of I-13I in the riyer was determined by the Hanford Laboratories to be about 1100 curies for $1964(5)$. The rate of transport is shown in curies per day during the year 1964 in Figure 1.

\section{Contribution from Ruptured Fuel}

The amount of I-13I released into the coolant stream from the fuel element ruptures was determined from the weight of irradiated uranium lost and the I-13I concentration in the uraniun.

The weight loss was determined by reviewing records of the 97 individual ruptures. Most of the ruptures appeared to have lost about 25 grams, two appear to have lost as much as 100 grams, fourteen were classified in tine 50 to 75 gram range and twenty-two in the 1 to 10 gram range, for a total of $2.4 \mathrm{~kg}$ and 25 grams each on the average.

The fuel element most susceptible to cladding failure is located in the core tubes just downstream of the maximum flux.

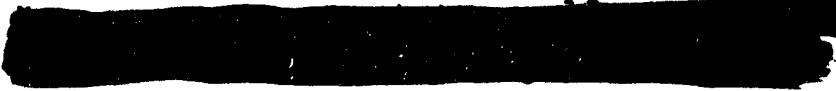

The equilibrium amount of I-13I created in $2.4 \mathrm{~kg}$ of irradiated uranilum at this power level is:

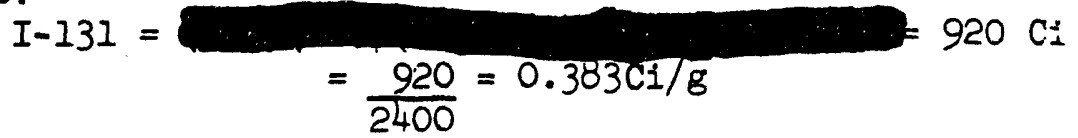

This result is probably conservative because all of the failures do not occur within this high a power level region.

The average daily release to the river, assuming all of the I-i3I is reieased, was determined from the I-13I in the uranium lost from each failed element. The results are plotted in Figlire 1 , based on the average for a 28 -day period so they can be compared with other results.

\section{Severe Failure, 1963}

The failure of a fuel element in the $\mathrm{KE}$ Reactor on $\mathrm{Mey} 12,1963$, resulted in the largegt single release of fissicn products to the river experienced at Fianford $(6)$. About 450 grams of uranium was lost from the elenent. 


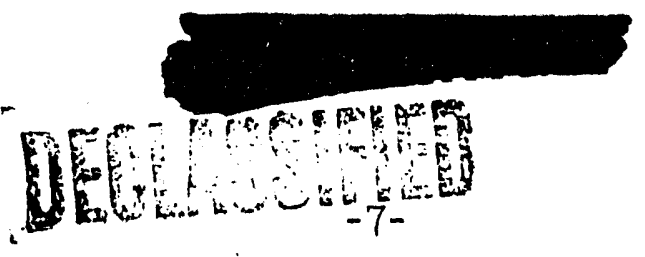

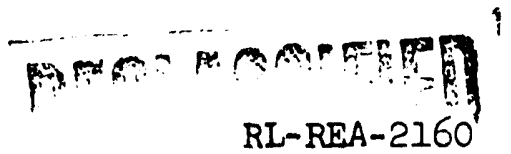

The automatic Columbia River monitor at 300 Area showed a rise in river activity which lasted 12 to 16 hours, peaking about four hours after arrival of the leading edge of the activity. The peak activity was about $60 \%$ above the background level. No ruptured fuel element during 1964 showed up so distinctly at the 300 Area river monitoring station.

The pound of irradiated uranium which was lost from the element is indicative of release of 170 curies of I-131. The cumulative sample taken at the 300 Area during the period May 6 to May 13, 1963, showed a concentration of $44 \mathrm{pCi} I-131 / 1$ and a transport of 100 curies of I-I3I past the point during the period.

Contribution from Uranium in Cooling Water

The amount of I-131 generated from the uranium present in the cooling water, was determined from the Np-239 water analysis $(7)(8)(9)(10)$ by direct ratio. During $1964,2 \times 10^{5}$ curies of $\mathrm{Np}-239$ was present in the reactor cooling water effluent. Assuming an average holdup time in the reactor of about 400 hours, the I-131/Np-239 ratio is 0.004 . This ratio is based on the build up of Np-239 from neutron capture by U-238 and the I-I3I from the fission of U-235 in the neutron flux present outside the fuel elements in the coolant tube (II). The assumed holdup time is based on work by both Perkins (4) and Silker (3) (i2) and confirmed py the ratio of I-13I to Np-239 found by reactor effluent sample analysis $(7)(13)(14)(15)$ in 1963 and early 1964.

The amount of I-13I from coolant water urantum during 1964 is:

$$
I-131=\left(2 \times 10^{5}\right)(0.004)=800 \mathrm{Ci} \text {. }
$$

The amount of $\mathrm{Np}-239$ present in the reactor cooling water effluent varled throughout the year, and it is assumed the I-I3I varies in direct proportion. The monthly contribution of I-I3I based on the Np-239 was calculated and the results plotted as $\mathrm{Ci} /$ atay in Figure 1 .

\section{Significance of the 1964 Fission Product Release}

The totai activity release from the reactors to the river was in the order of $6 \times 10^{6}$ curies corrected to a four hour decay. The total release of fission products was about $3.9 \times 1 \mathrm{C}^{4}$ curies, using the same decay correction, or about $0.7 \%$ of the total activity.

It is estimated that ruptured fuel elements contributed 920 curies of I-13I to the river. In addition the natural uranium present in river water used for cooling the reactors, upon irradiation contributed about 800 curies of I-13I making a total contribution of about 1700 curies.

The average river flow rate during 1964 was $131,500 \mathrm{cl} \mathrm{ft} / \mathrm{sec}(5)$. With tine above releases of $I-[3]$ to the river, the average concentration of $I-I .3 I$ in the river water totaled $14.5 \mathrm{pCi} / \mathrm{I}, 7.7 \mathrm{pCi} / 1$ from fuel element ruptures and $6.8 \mathrm{pCi} / \mathrm{l}$ from the Irradiation of the uranium in the cooling water. The 1100 curies measured

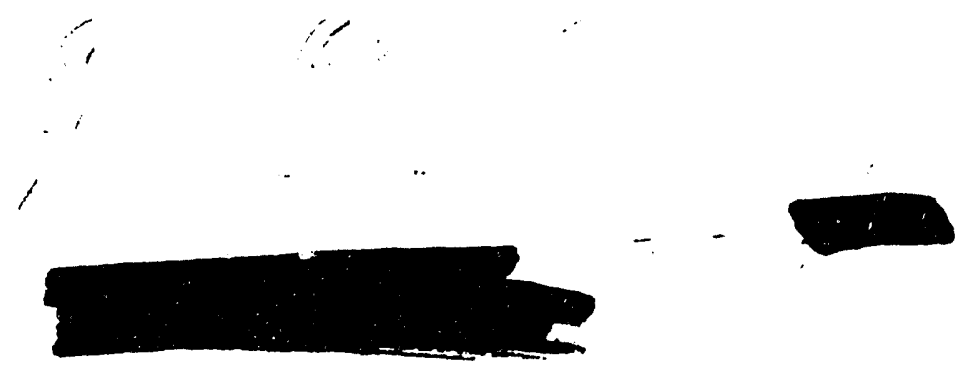


Federal Radiation Council Report No. 2 states that an average daily intake of 80 picocuries of I-13I meets the RPG for the thyroid for averages of suitable samples of an exposed population group of $0.5 \mathrm{rem}$ per year. Considering 2. litcr and $a$ half the average daily fluid intake for the standard man, the average daily intake rate from river water containing the I-I3I estimated to be released to the river was - $22 p \mathrm{pl}$. The averaon daily intake rate for measured values in the river water at Richland was $14 \mathrm{pCi}$.

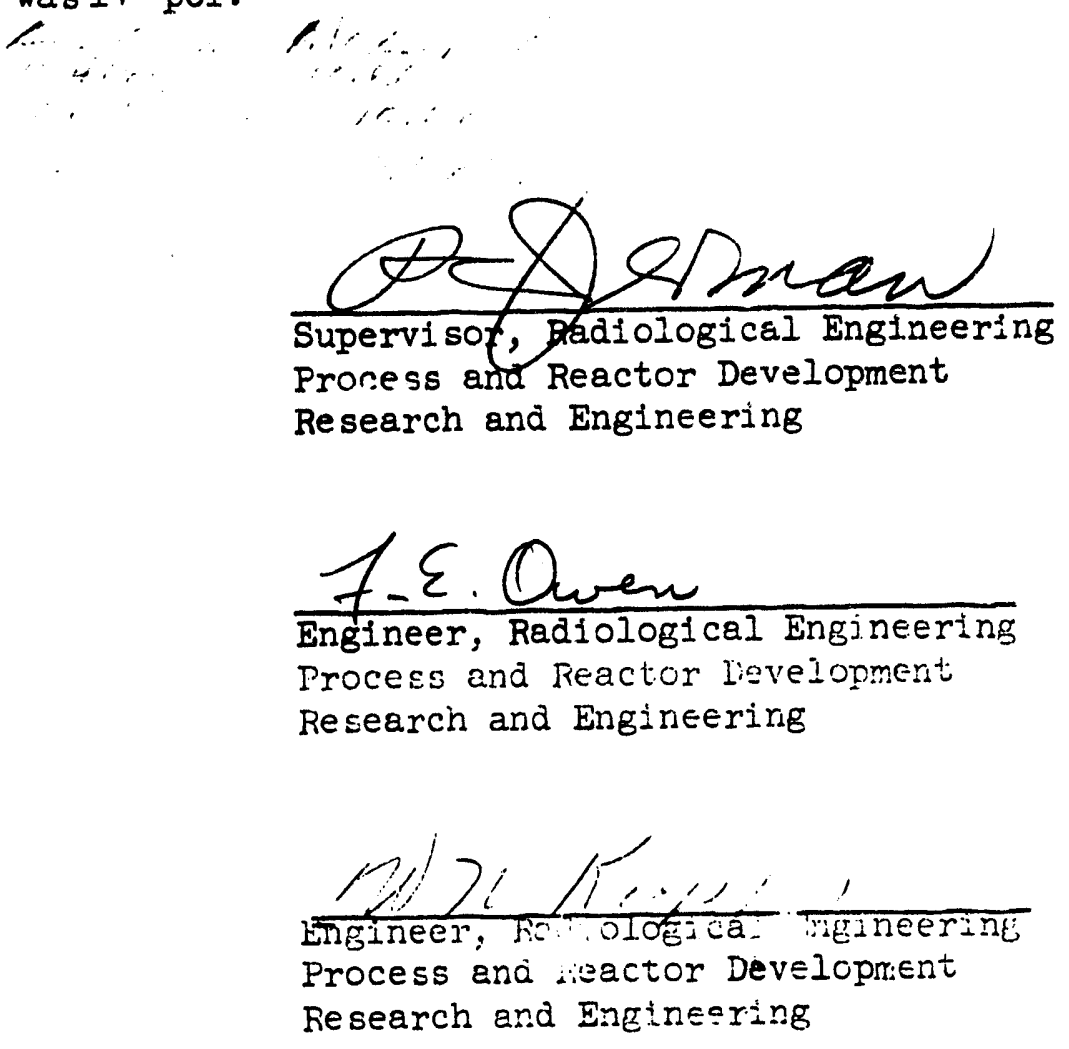

PC Jerman:WN Koop:FE' Oven:VS 


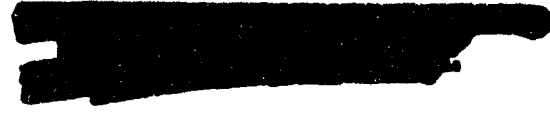

$-9-$

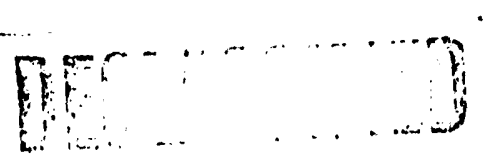

RI-REA-2: 60

References:

1. HW-61325, Significance of Rupture Debris in the Columbia River, J. D. McCormack and L.C. Schwendiman, August 17, 1959 (Confidential)

2. HW-80764, Slug Rupture Reports, 1964-Personal Secret Notebook, I. J. Newell.

3. HW-63633, Kinetics of Arsenic Retention in Hanford Reactor Cooling Systems, W. B. Silker, Feb. 11, 1960. (Secret)

4. HW-69969, Source of Reactor Effluent Water Radioisotopes; R. W. Perkins, May 1961. (Secret)

5. R. B. Hall, Private Communication.

6. HW-79073, Environmental Effects of a Fuel Element Failure, R. B. Hall, September 27, 1963. (Secret)

7. HW-81983, Reactor Effluent Analytical Date, January, February, Narch, 1964, W. N. Koop, Apr11 24, 1964. S.Secret)

8. HW-83423, Reactor Effluent Analytical Data Alril, May, June 1964, W. N. Koop, July 27, 1964. (Secret)

9. RL-REA-43, Regctor Effluent Analytical Data, Juiy, August, September, 1064 , W. N. Koop, October 26, 1964. (Secret)

10. RL-REA-498, Reactor Effluent AnalyticaI Data, October, Noveriber, December, 1964, W. N. Koop, January 20, 1965. (Secret)

11. R. H. Meichle, Private Communication.

12. W. B. Silker, Private Comunication.

13. HW-78820, Reactcr Effluent Analyt1cal Data, April, May, Iune, 1963, W. N. Koop, September 6, 1963. (Secret)

14. HW-79348, Reactor Effluent Analytical Data, July, August, September, I963. W. N. Koop, October 25, 1963. (Secret)

ir Viw Rn706. Reactor F Mant. Analntical Data, October, November, December 1963, W. N. Koop, Tebruary 7, 1963. (Secret)

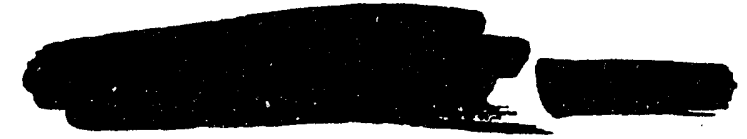



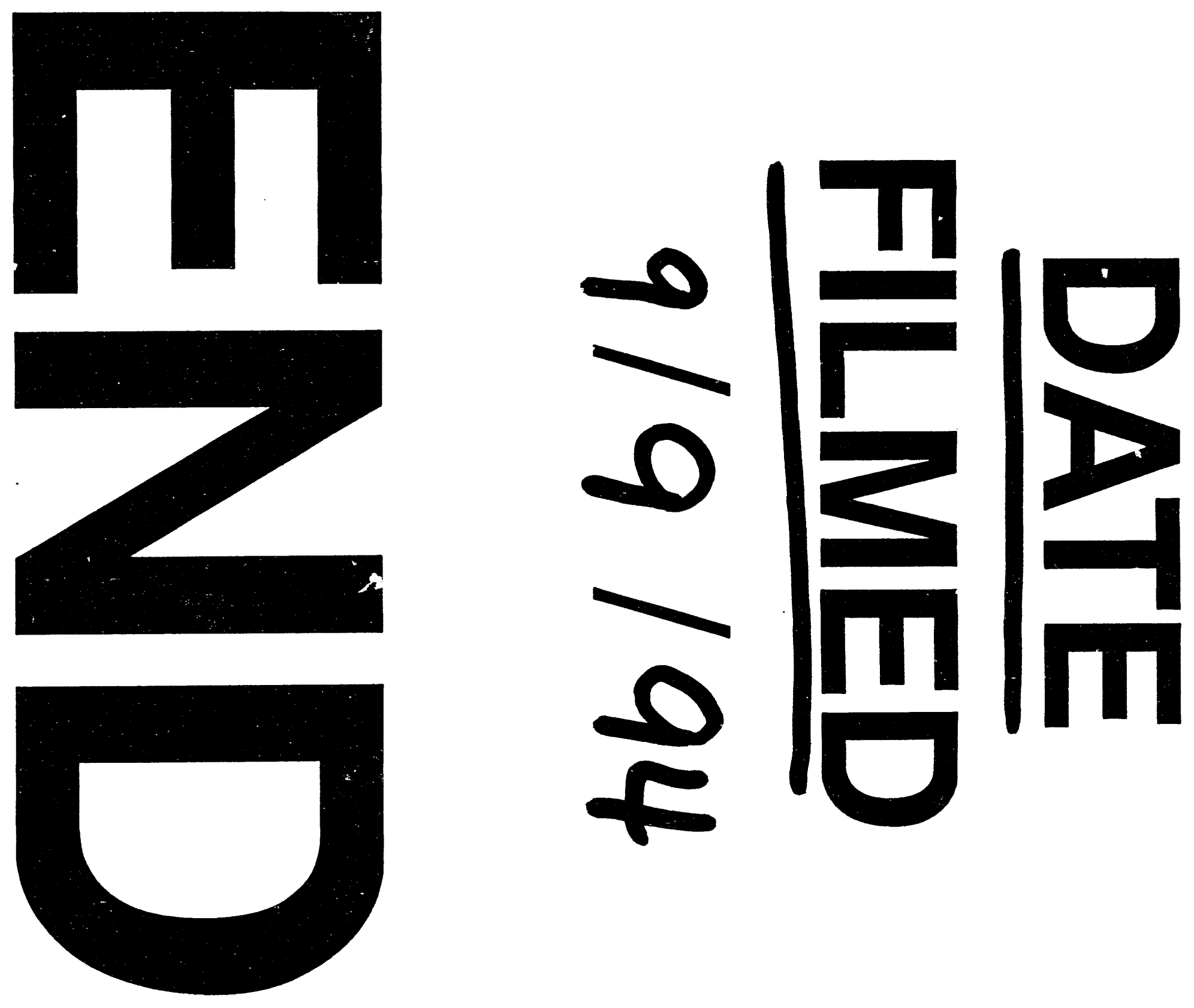